70 巻 695 号 $(2004-7)$

\title{
乳化剤無添加の乳化バイオディーゼルのディーゼル燃焼*
}

\author{
Choesnul JAQIN ${ }^{* 1}$, 浜 崎 和 則 ${ }^{* 2}$ \\ 木下英二*2, 亀 田 昭 雄 ${ }^{* 2}$
}

\section{Diesel Combustion with Emulsified Biodiesel without Adding Emulsifier}

\author{
Choesnul JAQIN, Kazunori HAMASAKI*3, \\ Eiji KINOSHITA and Akio KAMEDA \\ ${ }^{* 3}$ Department of Mechanical Engineering, Kagoshima University, \\ 1-21-40 Korimoto, Kagoshima-shi, Kagoshima, 890-0065 Japan
}

\begin{abstract}
Emulsified Biodiesel has lower $\mathrm{NO}_{x}$ and Smoke emissions compared with Biodiesel. In this study, a new emulsified Biodiesel with $15 \mathrm{wt} \%$ water is made without adding any emulsifier, and the combustion characteristics and exhaust emissions for the new fuel are investigated using a DI diesel engine. The new fuel has shorter ignition delay and lower $\mathrm{CO}, \mathrm{HC}$, Smoke and Aclorein emissions compared with the $15 \mathrm{wt} \%$ water emulsified Biodiesel with adding $0.1 \mathrm{wt} \%$ crude glycerin as an emulsifier. Moreover, the effect of the crude glycerin content on emulsified Biodiesel combustion is investigated. The emulsified Biodiesel has larger water droplet size and lower viscosity with decreasing crude glycerin content, and as the result, the ignition delay becomes shorter, and the HC, $\mathrm{CO}$, Smoke and Aclorein emissions become lower.
\end{abstract}

Key Words: Diesel Engine, Alternative Energy, Biomass Energy, Liquid Fuel, Emulsified Fuel, Biodiesel, Exhaust Emission

1. 精

バイオディーゼルは生分解性が良く，硫黄分をほ とんど含まない再生可能な含酸素燃料であり，軽油に 比べて排気煙濃度が低减する．また，バイオディーゼ ルはカーボンニュートラルな燃料と考えることができ， その燃焼によって排出される $\mathrm{CO}_{2}$ は植物の成長過程 で吸収される $\mathrm{CO}_{2}$ とバランスするので, バイオディ 一ゼルを軽油の一部代替燃料として使用することは $\mathrm{CO}_{2}$ の削減に寄与することになると思われる.

著者らは，これまでに，バイオディーゼルに水を 添加して乳化した乳化バイオディーゼルを作製し, 直 噴式ディーゼル機関を用いて燃焼・排出ガス特性に関 する実験を行い，乳化バイオディーゼルがバイオディ 一ゼルに比べて燃焼を改善させ，排出ガス中の NOx と排気煙濃度を同時に低减させることを報告 (1) した。 前報 ${ }^{(1)}$ では, バイオディーゼルを作製する際の副生 物である粗製グリセリンを乳化剤として $0.1 \mathrm{wt} \%$ 使用 しているが，乳化剂の粗製グリセリン添加量は燃料の

\footnotetext{
* 原稿受付 2003 年 9 月 22 日.

*1 正員, 鹿児島大学大学院理工学研究科(-890-0065 鹿児島 市郡元 1-21-40)

*2 正員, 鹿児島大学工学部.

E-mail : hamasaki@ mech.kagoshima-u.ac.jp
}

釈化状態を変化させるので, 燃焼およひ排出ガス特性 に影響を及ぼすと思われる. また，乳化剂の粗製グリ セリンはそのほとんどがグリセリンであり,グリセリ ンは $290^{\circ} \mathrm{C}$ 以上において熱分解によりアクロレイン （アクリルアルデヒド）に変化する ${ }^{(2)}$. 粗製グリセ リンを使用した乳化バイオディーゼル燃焼の排出ガス 中にはバイオディーゼルに比べてアクロレインを多く 含む可能性があり，粗製グリセリンの使用量はなるべ く少ない方が望ましいと思われる.アクロレインは、 自動車の排出ガス規制対象物質ではないが、平成 13 年 4 月施行された法律 ${ }^{(3)}$ によって第 1 種指定化学物 質 (354 種) に指定されている.

本研究では, 以上のことを考虑して, 乳化剂の粗 製グリセリンを全く添加しない乳化バイオディーゼル の作製を試み，その結果，乳化剤無添加の安定した乳 化バイオディーゼルを作製することができた. この新 たに作製した乳化剂無添加の乳化バイオディーゼルを 直噴式ディーゼル機関に適用し，燃焼・排出ガス特性 について実験を行い，これまでの乳化剂の粗製グリセ リン添加量が $0.1 \mathrm{wt} \%$ の場合と比較検討した. また, 乳化剂の粗製グリセリン添加量を変えた燃料を作製し, 乳化バイオディーゼルの燃焼・排出ガス特性に及ぼす 粗製グリセリン添加割合の影響についても検討した. 


\section{2. 供 試 燃 料}

なたね油メチルエステル（RME）をべース燃料と して使用し, 乳化剂無添加の乳化なた放油メチルエス テル（ERE）と乳化剤の粗製グリセリンの添加量が 異なる $3 つ \mathrm{ERE}$ を作製した。作製した 4 種類の ERE は最適水混合割合の $15 \mathrm{wt} \%$ である ${ }^{(1)}$. ERE は覮抖 機を用いて作製するが，機械的条件等が乳化状態（乳 化水粒子の粒径分布等）に影響を及ぼすので，擋拌機 の回転数，時間および温度をほぼ同じ（約 $25^{\circ} \mathrm{C）に}$ して作製した

表 1 に RME と JIS 2 号軽油の燃料性状を示寸. RMEのエステル変換率は 95\%以上である．RMEは 酸素を $10.5 \%$ 程度含有しており，硫黄をほとんど含 有していない. RME の動粘度は軽油の 1.5 倍程度で あり，比較的低粘度である，また， RME の低発熱量 は軽油の $85 \%$ 程度である。

表 2 に作製した ERE の質量組成，100 個の乳化水 粒子のザウタ平均粒径（S.M.D.）および動粘度を示 し, 図 1 に乳化状態の顕微鏡写真を示す．表 2 の S.M.D.は図 1 の顕微鏡写真の測定值であり, また, 動粘度はレッドウッド粘度計による実測值である. EREg0 は乳化剤無添加の ERE である. EREg0.1 は 前報の実験 ${ }^{(1)}$ で用いた水混合割合 $15 \mathrm{wt} \%$ の乳化バ イオディーゼルと同じ質量組成であり，S.M.D.もほ ぼ同じである（前報 (1) の水混合割合 $15 \mathrm{wt} \%$ の乳化 水粒子径の S.M.D.は $121 \mu \mathrm{m}$ ) 。

図 1 より，乳化剂の粗製グリセリンの添加割合が異 なると乳化状態が明らかに異なり，粗製グリセリンの 添加割合が増加するほど乳化水粒子径が小さくなり, 水粒子径が均一で安定な乳化状態になっていることが 分かる. ERE はW/O 型エマルジョンである. 表 2 よ り, 乳化剈の粗製グリセリンの添加割合が減少する ほど S.M.D.が大きくなり, 動粘度が減少している. また, 表 2 の ERE の動粘度は RME に比べて大きい. ERE は球状多分散系のエマルジョン ${ }^{(4)}$ であるので, 表 2 に示した動粘度はレッドウッド粘度計の測定によ る見かけの值であり，この動粘度が ERE のディーゼ ル噴霧の微粒化特性にどのように影響寸るのかは明ら かではない，動粘度の増加による影響はあると考えら れるが, ERE は RME に比べて着火は遅れるものの 燃焼は良好 ${ }^{(1)}$ なので, ERE の噴霧の微粒化は, 表 2 の動粘度の増加が示寸ほどには悪化しないと思われ る.

図 2 に時間経過に対する ERE の分離率を示す. ERE が分離すると上層に RME，下層に水が分離し，
Table 1 Properties of RME and gas oil

\begin{tabular}{|c|c|c|c|}
\hline \multicolumn{2}{|l|}{ Fuel } & RME & Gas Oil \\
\hline \multicolumn{2}{|l|}{ Cetane number } & 51 & 56 \\
\hline Net calorific value & $\mathrm{MJ} / \mathrm{kg}$ & 36.55 & 43.12 \\
\hline Density@288K & $\mathrm{kg} / \mathrm{m}^{3}$ & 886 & 832 \\
\hline Viscosity@293K & $\mathrm{mm}^{2} / \mathrm{s}$ & 7.7 & 4.7 \\
\hline Pour point & ${ }^{\circ} \mathrm{C}$ & -7.5 & -12.5 \\
\hline $\mathrm{C}$ & wt $\%$ & 77.6 & 87.3 \\
\hline $\mathrm{H}$ & wt $\%$ & 11.9 & 12.5 \\
\hline $\mathrm{O}$ & wt $\%$ & 10.5 & 0 \\
\hline Sulfur & wt $\%$ & 0.0006 & 0.05 \\
\hline Water & wt $\%$ & 0.03 & - \\
\hline \multicolumn{2}{|c|}{ Stoichiometric air-fuel ratio } & 12.57 & 14.2 \\
\hline
\end{tabular}

Table 2 Properties of test fuels

\begin{tabular}{lr|c|c|c|c}
\hline & & EREg0 & EREg0.1 & EREg0.5 & EREg1.0 \\
\hline \hline RME wt \% & 85 & 84.9 & 84.5 & 84 \\
\hline Water wt \% & 15 & 15 & 15 & 15 \\
\hline \multicolumn{2}{l|}{ Emulsifier wt \% } & 0 & 0.1 & 0.5 & 1 \\
\hline \multicolumn{2}{l|}{ S.M.D. $\mu \mathrm{m}$} & 170 & 113 & 26 & 15 \\
\hline \multicolumn{2}{|l|}{$\begin{array}{r}\text { Viscosity@313K } \\
\mathrm{mm}^{2} / \mathrm{s}\end{array}$} & 13.8 & 18.8 & 57.5 & 87.4 \\
\hline
\end{tabular}

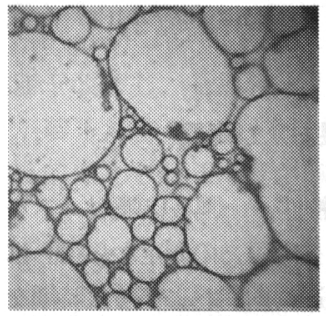

EREg0

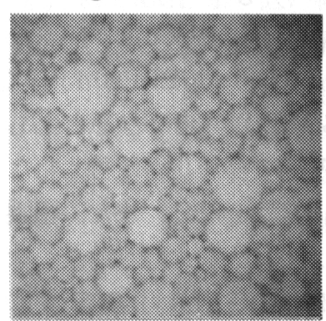

EREg0.5

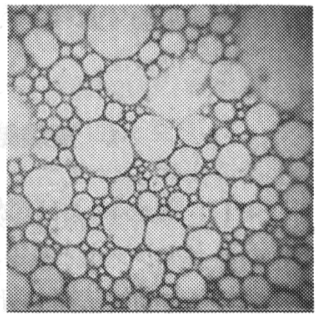

EREg0.1

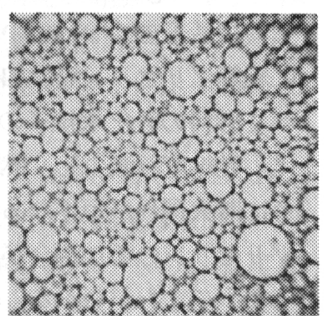

EREg1.0
Fig. 1 Emulsified particles in microscopic photos 
中間層が ERE となる. 上層の分離率 $b / a$ は下層の分 離率 $c / a$ より大きいことが分かる. 乳化剂の粗製グリ セリンの添加割合が増加するほど, 上層および下層の 分離率が減少している. EREg0 は 300 時間経過して も，上層および下層とも分離を起こしていないので, EREg0 は作製してから使用するまで十分に安定した 乳化状態を保つことができると思われる.

今回, 乳化剂無添加の ERE を作製することができ たが, RME 中に微量に残留している遊離グリセリン (モノグリセリド, ジグリセリド等) が乳化剂として 働いているものと考えられる. 以下のディーゼル燃 焼・排出ガス特性の実験には, 供試燃料として EREg0, EREg0.1, EREg0.5, EREg1.0 および比較 のためにRME を使用した.

\section{3. 実硂装置および方法}

供試機関は単気筒，水冷式，横型，直噴式四サイク ルディーゼル機関で, 表 3 に主要諸元を示す. 噴射系 は軽油使用時の標淮噴射系を用いた，排出ガス中の CO 濃度は NDIR, NOx 濃度は CLD, HC 濃度は FID, 排気煙濃度はボッシュ式スモークメータおよび アクロレイン濃度はガスクロマトグラフ (FID) を使 用して測定した。噴射ノズルのニードルリフトはホー ル素子センサにより測定し, シリンダ内圧力はひずみ ゲージ式高圧指圧計によって測定した. ニードルリフ トおよびシリンダ内圧力は 50 サイクルの平均值であ る. 実験は, 機関回転数を $2000 \mathrm{rpm}$ 一定として負荷 （負荷 $100 \%$ で正味平均有効圧力は $0.67 \mathrm{MPa}$ ）を変 化させて行った.

\section{4. 実験結果および考寮}

$4 \cdot 1$ 着火および然焼特性 図3に噴射ノズル のニードルリフトとシリンダ内圧力の測定から得られ た燃料噴射開始時期，着火遅れ期間および着火時期を 示す. EREg0の着火遅れは EREg0.1 に比べて全ての 負荷で若干短くなっている. これは, 表 2 に示すよう に粗製グリセリン無添加の EREg0 は EREg0.1 に比 べて燃料の乳化水粒子の S.M.D.が大きくなるととも に, 動粘度が减少し, 燃料噴霧の微粒化が改善したた めに着火遅れが短くなったと考えられる. また, 粗製 グリセリンの添加割合が増えるほど着火遅れは長くな っていることが分かる. 特に, EREg1.0は EREg0に 比べて着火遅れがクランク角約 $0.5 \sim 1.0 \mathrm{deg}$. 長くな っている. 着火遅れが長くなる理由は, 粗製グリセリ ンの添加割合が増えるほど乳化水粒子の S.M.D.が小

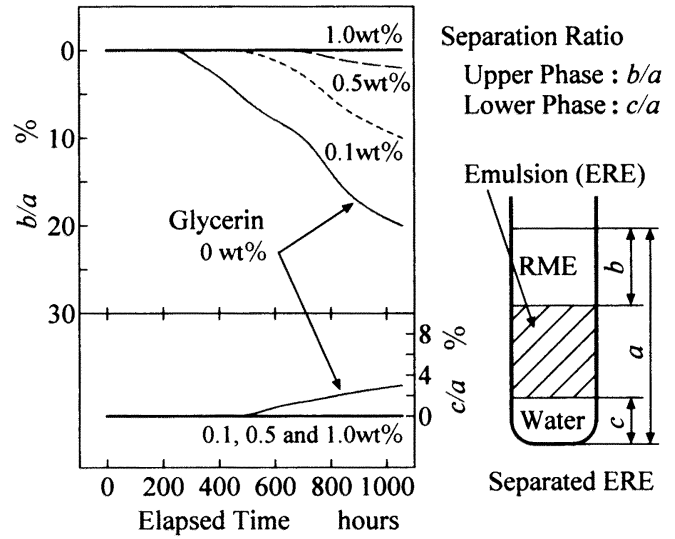

Fig. 2 Separation of RME and water from ERE

Table 3 Specifications of test engine

\begin{tabular}{l|l}
\hline Engine Type & $\begin{array}{l}1 \text { Cylinder, 4 Stroke, } \\
\text { D.I., Water Cooled }\end{array}$ \\
\hline Bore $\times$ Stroke & $110 \times 106 \mathrm{~mm}$ \\
\hline Stroke Volume & $1007 \mathrm{~cm}^{3}$ \\
\hline Compression Ratio & 16.3 \\
\hline Rated Power & $11.77 \mathrm{~kW} / 2200 \mathrm{rpm}$ \\
\hline Nozzle Opening Pressure & $19.6 \mathrm{MPa}$ \\
\hline Nozzle Holes & $\phi 0.33 \mathrm{~mm} \times 4$ \\
\hline
\end{tabular}

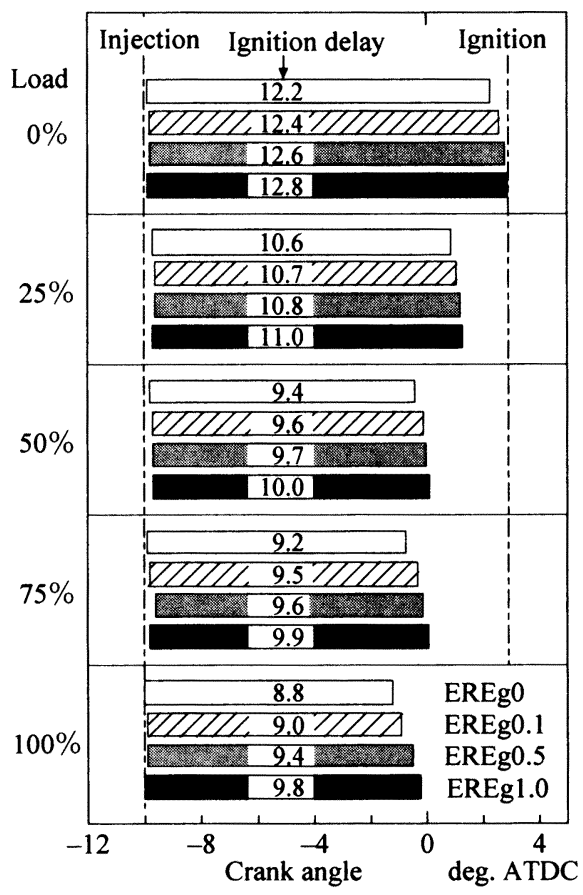

Fig. 3 Injection and ignition timing 


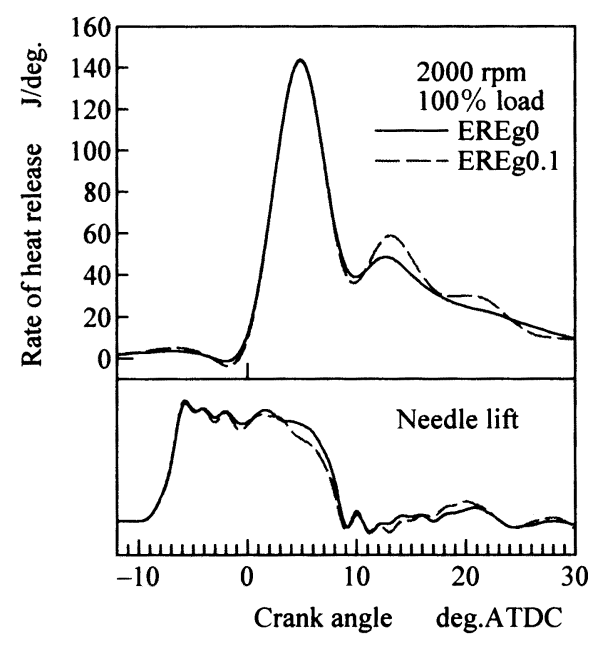

Fig. 4 Rate of heat release and needle lift

さくなり動粘度が増加し, 燃料噴霧の微粒化が 悪化したことによると考えられる.

図4に，負荷 $100 \%$ におけ EREg0 と EREg0.1 の熱発生率線図と噴射ノズルのニードルリフトを示す. ニードルリフトは両然料間でほぼ同じである. 図3に 示すように EREg0の着火遅れは EREg0.1 より若干短 いが, 図 4 より, EREg0 と EREg0.1 とでは, 着火後 の最大熱発生率はほほ同じであり, その後の熱発生率 もあまり変わらないことが分かる.

$4 \cdot 2$ 機関性能と排出ガス特性 図5 に正味熱 効率 BTE と排出ガス中の NOx 濃度, 排気煙浱度, $\mathrm{CO}$ 鋠度および HC 鋠度を示す. ERE 系燃料の正味熱 効率は RME とほほ同じ値を示しており, EREg0 と EREg0.1の正味熱効率に違いは見られない.

図 5 の HC 濃度は各供試燃料とも低負荷側で高い值 を示寸. ERE 系燃料の HC 垠度は RME より高い值を 示し, 粗製グリセリン添加割合が減少するほど, HC 濃度は减少していることが分かる．また， EREg0の HC 嶩度は EREg0.1 より若干低い值を示している. こ れは, 前述したように, EREg0 は EREg0.1に比べて 燃料の乳化水粒子 S.M.D.の増大による動粘度の減少 のため, 燃料噴霧の微粒化が若干改善したこと，それ にともない，着火遅れが若干短くなったことによ り, 低温の雾囲気空気に凍結される燃料の量が 少なくなり， HC 湦度が減少したと考えられる.

$\mathrm{CO}$ 濃度は各供試然料とも低負荷側およひ高負荷側 で増加している. ERE 采燃料の CO 濃度は RME よ り高い值を示し, 粗製グリセリン添加割合が减少する

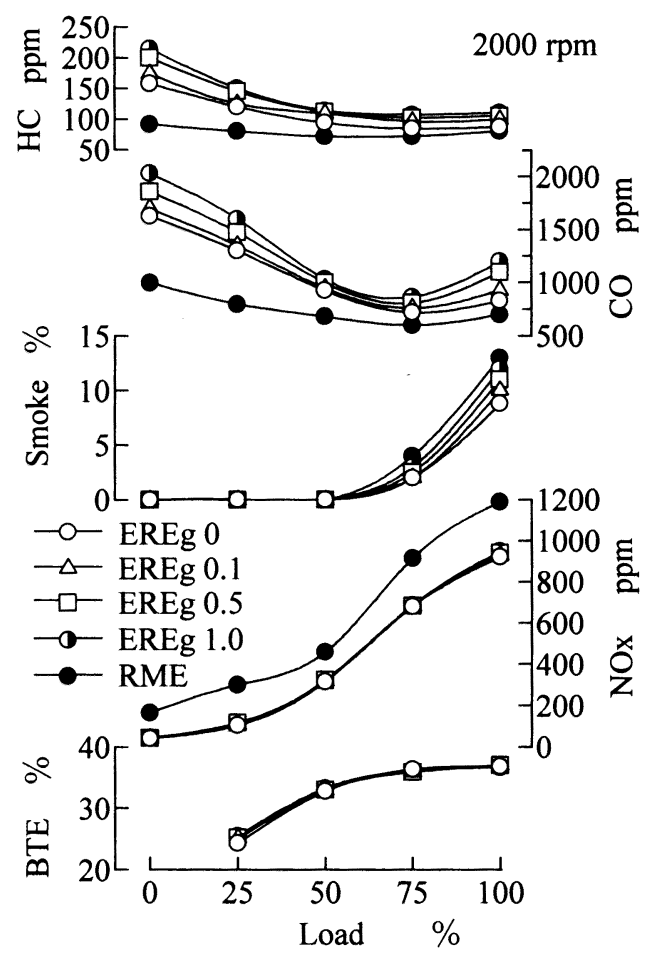

Fig. 5 BTE and exhaust emissions

ほど, CO 濃度は減少していることが分かる. EREg0 の CO 濃度は EREg0.1 より若干低い值を示している. これは, EREg0の HC 濃度低减の理由と同様に, EREg0.1に比べて, EREg0の燃料噴霧の微粒化が 若干改善し, それにともない EREg0 の着火遅れ が若干減少したため, 低温の雾囲気空気により 反応停止される $\mathrm{CO}$ が減少したためと考えられる.

図 5 の排気煙濃度はいずれの供試然料においても 負荷 $25 \%$ までは全く排出されておらず，負荷 $50 \%$ 以 降において急激に増加している. ERE 系然料の排気 煙濃度は RME より低い值を示し，粗製グリセリン添 加割合が减少するほど, 排気煙濃度は减少しているこ とが分かる. 負荷 100\%では EREg0.1 に比べEREg0 は約 10\%の低减が見られる.

NOx 濃度は各供試燃料とも負荷が増えるにつれて 增加している. ERE 系燃料の NOx 濃度は RME より 低い值を示しており，EREg0の NOx 濃度は EREg0.1 の場合とほぼ同じ値を示す.これは, 図 4 に示すように着火後の最大熱発生率がほぼ同じ值にな ったためであると考えられる。一方, EREg0.1， EREg0.5, EREg1.0 と粗製グリセリン添加割合が 


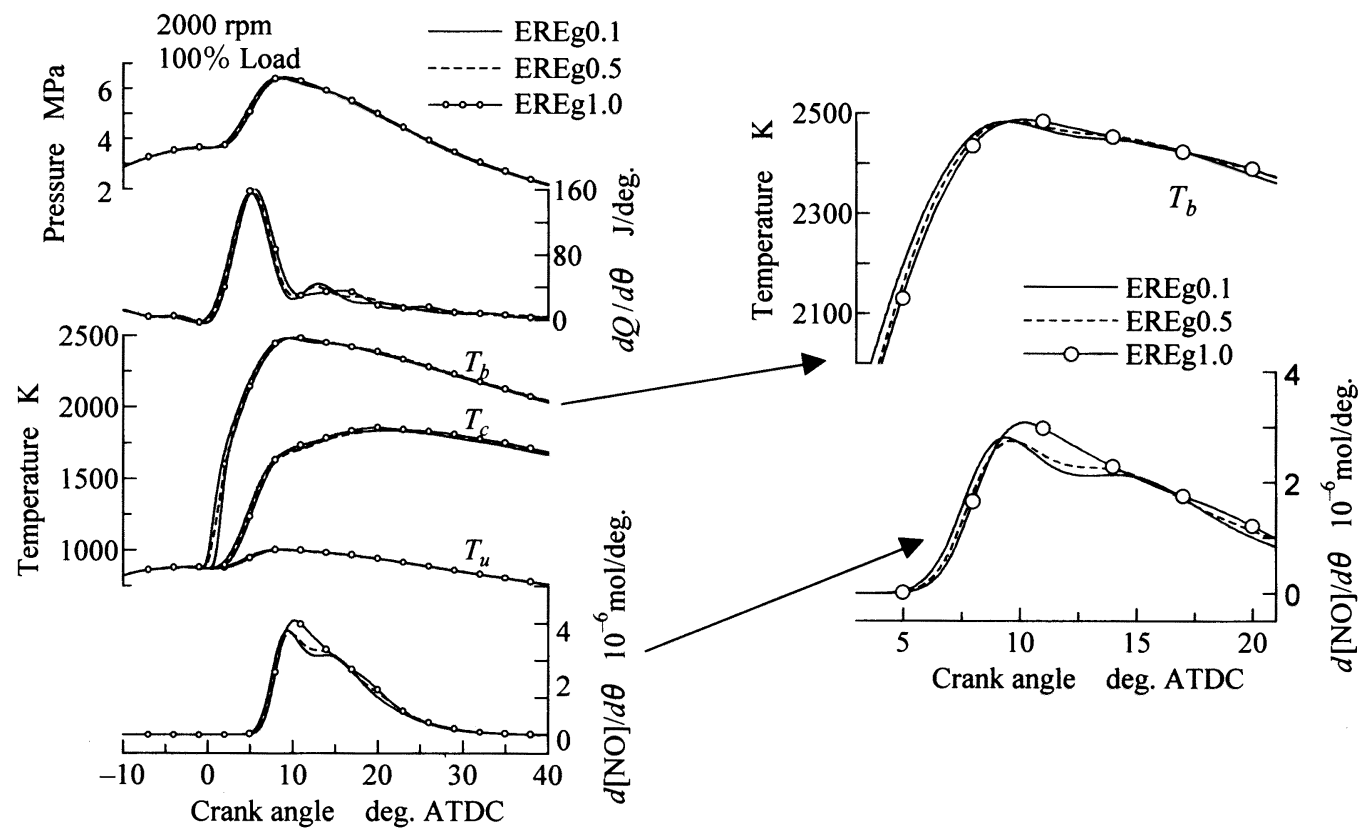

Fig. 6 NO formation rate by two-zone model (2000 rpm, 100\% load)

増加すると, 負荷 0〜 75\%までは, NOx 濃度はほぼ 同じであるが，負荷 $100 \%$ では，粗製グリセリン添加 割合が増加するほどNOx 濃度が若干増加している.

図 6 に負荷 $100 \%$ の場合に対して, EREg0.1, EREg0.5 および EREg1.0 のシリンダ内圧力, 熱発生 率 $d Q / d \theta$, 石田らの 2 領域モデル (5) (6) により計算 した燃焼域温度 $T_{b}$, 筒内平均温度 $T_{c}$, 未燃域温度 $T_{u}$ および NO 生成率 $d[\mathrm{NO}] / d \theta$ を示している. 石田ら の 2 領域モデルは, 実測のシリンダ内圧力とそれから 求めた熱発生率により計算するものである. NO 生成 率の計算には拡大ゼルドビッチ機構の反応速度式を用 いており, NO 生成率の積算值が実測の NOx 濃度と 一致するように計算を行っている. 図6によると, 粗 製グリセリン添加割合が増加するほど着火は遅くなり, そのために燃焼域温度は遅い時期から上昇している. また, 粗製グリセリン添加割合が増加するほど着火後 の最大熱発生率が若干高くなっている. そのため, ク ランク角 $\theta=3 \sim 10 \mathrm{deg}$. ATDCにおいて, 燃焼域温 度は粗製グリセリン添加割合が大きいほど若干高くな っている. 燃燒域温度が高くなる $\theta=5 \sim 20 \mathrm{deg}$. ATDC において NO は生成しており, NO 生成率は 粗製グリセリン添加割合が増加するほど $\theta=9 \sim 15$ deg. ATDC において若干大きくなっている. 負荷 $100 \%$ において粗製グリセリン添加割合の増加による

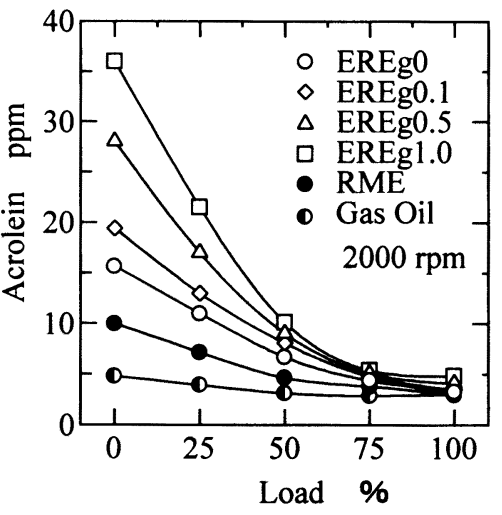

Fig. 7 Acrolein emissions of EREs

NOx 濃度の若干の増加（図 5) は, 着火遅れの増大 に起因する最大熱発生率の増加によって燃焼温度が若 干上昇したことによると考えられる.

図 7 にガスクロマトグラフを用いて測定した排出ガ ス中のアクロレイン濃度を示す. 図7には軽油のデー タ (7) も示している. 全ての燃料で, アクロレイン灙 度は負荷が増加するほど減少している. ディーゼル機 関から排出されるアクロレインは, 着火遅れ期間の炭 化水素の部分酸化によって形成される ${ }^{(8)}$ ので, 燃焼 室内で形成されたアクロレインは, 負荷が増加するほ 
ど再燃焼される割合が大きくなり，アクロレイン排出 濃度が減少したと考えられる. ERE のアクロレイン 湢度は RME や軽油に比べて高く, また, 釈化剤の 粗製グリセリンの添加割合が減少するほど低くなって おりこれらのことは低負荷域において顕著である. 乳化剂の粗製グリセリンは，そのほとんどがグリセリ ンであり,グリセリン $\left(\mathrm{C}_{3} \mathrm{H}_{8} \mathrm{O}_{3}\right)$ は次式に示すよう に, $290^{\circ} \mathrm{C}$ 以上の高温状態で熱分解によりアクロレイ ン $\left(\mathrm{CH}_{2} \mathrm{CHCHO}\right.$, アクリルアルデヒド $)$ を生成 ${ }^{(2)}$ する.

$$
\mathrm{C}_{3} \mathrm{H}_{8} \mathrm{O}_{3} \rightarrow \mathrm{CH}_{2} \mathrm{CHCHO}+2 \mathrm{H}_{2} \mathrm{O}
$$

したがって，ERE の粗製グリセリン添加割合の减少 はアクロレイン排出濃度を減少させる一因であると考 えられる. また, ERE の粗製グリセリン添加割合が 减少するほど着火遅れが短くなるので, このこともア クロレイン排出濃度の堿少の原因と考えられる.

以上のことから, EREg0 は EREg0.1 に比べて, 着火遅れが若干短くなるとともに, $\mathrm{HC}, \mathrm{CO}$, 排気 煙濃度およびアクロレイン濃度が低减し, また, 乳化 燃料の分離もほとんど変わらないので, EREg0 の方 が EREg0.1 に比べて優れた乳化バイオディーゼルで あると言える.つまり，乳化剤の粗製グリセリンは添 加しない方が良いということである. 今回製作した乳 化剂無添加の乳化バイオディーゼルは約 300 時間分 離しない比較的安定した乳化然料であるので，さらに 長時間の乳化状態の維持が必要な場合を除いて, 乳化 郕を使用する必要はないと考えられる. 長時間の乳化 状態の維持が必要な場合, 添加する乳化剂が燃焼や排 出ガスを改善させるものなら好ましいが，排出ガス等 を悪化させる要因を作るなら, 当然のことであるが乳 化剂の添加量に対し注意が必要である.

\section{5. 結}

乳化剂無添加の乳化バイオディーゼルを直噴式デ
イーゼル機関に適用して, 燃焼・排出ガスに関する寒 験を行い，乳化剤の粗製グリセリンを $0.1 \mathrm{wt} \%$ 使用し て作製したこれまでの乳化バイオディーゼルの場合と 比較検討した. また, 乳化剂の粗製グリセリンの添加 量を変えた場合の実験も行い，その燃焼・排出ガス特 性について検討した. その結果, 以下の結論を得た.

（1）乳化剤無添加の乳化バイオディーゼルは, 乳 化剂の粗製グリセリンを $0.1 \mathrm{wt} \%$ 使用したものに比べ て, 着火遅れが若干短くなるとともに, 排出ガス中の $\mathrm{HC}, \mathrm{CO}$, 排気煙およびアクロレイン濃度が改善す る.

（2）乳化剤無添加の乳化バイオディーゼルは, RME や乳化剤として粗製グリセリンを使用した場合 に比較して, 排出ガス中の NOx 濃度に变化はないが, 排気煙濃度は改善する。

（3）乳化剂の粗製グリセリン添加割合が増加する ほど, 燃料中の乳化水粒子のザウタ平均粒径が小さく なり, 動粘度が増加する.

終わりに, 本研究の一部は平成 15 年度文部科学省 科学技術振興調整費により害施され，実験には大学院 生石川君の協力を得た。ここに記して謝意を表します。

\section{文献}

(1) 浜崎和則・ほか3名, 機输, 67-663, B (2001), 2898-2904.

(2) 藤谷揵, あぶら (油脂)の話, $(2000), 94$, 裳華房.

(3) 特定化学物質の環境一の排出量の把握等及び管理の改善の促 進に関する法律, 平成 13 年 4 月施行.

(4) 北原・古澤, 分散- 乳化系の化学, (1983), 61-63, 工学図書.

(5) 石田正弘・ほか 4 名, 機論, 60-573, B(1994), 1845-1851.

(6) 石田正弘・陳之立, 機論, 61-590, B (1995), 3541-3547.

(7) Hamasaki, K., et al., COMODIA2001, (2001), 410-416.

(8) Patterson, D. J. and Henein, N. A., "Emissions From Combustion Engines and Their Control," ann arbor science, Michigan, (1972), p.139. 